\title{
Radiofrequency thermocoagulation combined with pulsed radiofrequency for gasserian ganglion blockage
}

\author{
Gasser ganglion blokajında pulse radyofrekans ile termokoagülasyon radyofrekansın \\ kombine edilmesi
}

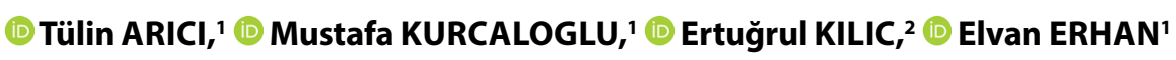

\begin{abstract}
Summary
Objectives: Trigeminal neuralgia (TN) has been effectively treated by radiofrequency thermocoagulation (RFT) of the gasserian ganglion. Recently, pulsed radiofrequency (PRF) is becoming an alternative therapy for patients with trigeminal neuralgia. It is unclear whether the combination of RFT with PRF may decrease post-operative complications while maintaining longterm pain relief.

Methods: Twelve patients with idiopathic TN who had undergone combined RFT and PRF of the gasserian ganglion were evaluated. PRF ( $42^{\circ} \mathrm{C}, 45 \mathrm{~V}, 20 \mathrm{~ms}, 120$ seconds) was administered, and then RFT ( $65^{\circ} \mathrm{C}, 90$ seconds) was performed to the gasserian ganglion. The post-operative pain relief and complications were evaluated at 1, 6, 12 and, 24 months after treatment.

Results: 10 patients (83.3\%) reported significant pain relief (VAS 3) at 1 month following the treatment, while 8 patients $(66.6 \%)$ at 6 months, 5 patients (41.6) at 12 months, and 2 patients (16.6\%) at 24 months were pain-free. Two of the patients did not have pain relief (VAS $\geq 3$ ), and 2 patients were still pain-free by the $24^{\text {th }}$ month. The mean time of pain relief was 14 months. One patient had numbness in the tongue for about a year, while in the other patients, no serious complications were reported. Conclusion: A combination of RFT with PRF could help eliminate postoperative complications of trigeminal neuralgia. We sugesst that combining RFT and PRF therapy may serve to decrease the side effects but not increase the pain relief.
\end{abstract}

Keywords: Gasserian ganglion blockage; pulsed radiofrequency; radiofrequency thermocoagulation; trigeminal neuralgia.

\section{Özet}

Amaç: Trigeminal nevralji (TN), gasserian ganglionun radyofrekans termokoagülasyonu (RFT) ile etkin bir şekilde tedavi edilmiştir. Son zamanlarda, pulse radyofrekans (PRF) trigeminal nevraljisi olan hastalar için alternatif bir tedavi haline gelmektedir. RFT ile PRF kombinasyonunun postoperatif komplikasyonları azaltıp azaltmadığı ve uzun süreli ağrıların giderilip giderilmediği belirsizdir.

Gereç ve Yöntem: Gasser ganglionun kombine RFT ve PRF'si uygulanan idiopatik TN'lı 12 hasta değerlendirildi. PRF $\left(42^{\circ} \mathrm{C}, 45\right.$ V, 20 ms, 120 saniye) uygulandı ve daha sonra, Gasser gangliona RFT ( $65^{\circ} \mathrm{C}, 90$ saniye) yapıldı. Postoperatif ağrı rahatlaması ve komplikasyonları tedaviden 1, 6, 12 ve 24 ay sonra değerlendirildi. Ağrı için VAS 3 ve üzeri dikkate alındı.

Bulgular: 10 hastada (\%83.3) tedaviden 1 ay sonra ağrıda belirgin azalma varken, 6. ayda 8 hasta (\%66.6), 12. ayda 5 hasta (\%41.6) ve 24. ayda 2 hasta (\%16.6) ağrısızdı. Hastaların 2'sinde ağrı rahatlaması yoktu (NRS $\geq 3$ ) ve 24. ayda 2 hasta hala ağrısızdı. Ağrı rahatlama süresi ortalama 14 aydı. Bir hastada yaklaşık bir yıldır dilde uyuşma vardı, diğer hastalarda ise ciddi komplikasyonlar bildirilmedi.

Sonuç: PRF ile RFT kombinasyonu, trigeminal nevraljinin postoperatif komplikasyonlarını ortadan kaldırabilir. RFT ve PRF tedavisini kombine etmenin yan etkilerin azaltılmasına hizmet edebileceğini ancak ağrıyı azaltmadığını belirtmek isteriz.

Anahtar sözcükler: Gasser ganglion blokajı; pulse radyofrekans; radyofrekans termokoagülasyon; trigerminal nevralji.

\section{Introduction}

Trigeminal neuralgia (TN) is a pain syndrome characterised by paroxysmal severe pain originating from the trigeminal nerve and has been effectively treated by radiofrequency thermocoagulation (RFT) of the gasserian ganglion in patients unresponsive to rou-

'Department of Anaesthesiology, Reanimation and pain, Ege University Faculty of Medicine, İzmir, Turkey

2Department of Anaesthesiology, Reanimation and Pain, Dr. Ersin Arslan Research and Training Hospital, Gaziantep, Turkey

Submitted (Başvuru tarihi) 28.03.2018 Accepted after revision (Düzeltme sonrası kabul tarihi) 11.09.2018 Available online date (Online yayımlanma tarihi) 25.10.2018

Correspondence: Dr. Ertuğrul Kilic. Dr. Ersin Arslan Eğitim ve Araştırma Hastanesi, Anesteziyoloji ve Reanimasyon Kliniği, 27070 Gaziantep, Turkey.

Phone: +90 - 533 - 6304875 e-mail: drertugrulkilic@yahoo.com

(c) 2018 Turkish Society of Algology 
tine medication therapy ${ }^{[1,2]}$ RFT has often been used because of its effectiveness in providing long-term pain relief. However, in patients who underwent RFT therapy, some complications such as facial numbness, masseter weakness, decreased corneal reflex, dysesthesia, and anaesthesia dolorosa have been reported. ${ }^{[3]}$ Recently, pulsed radiofrequency (PRF) is becoming an alternative therapy for patients with TN. Despite some controversial results, the efficacy of PRF of gasserian ganglion, its safe reputation ${ }^{[4,5]}$ and was as its effectiveness ${ }^{[6]}$ have been demonstrated. It is unclear whether the combination of RFT with PRF may decrease post-operative complications while maintaining long-term pain relief.

In this study, we evaluated patients with TN who had undergone combined RFT and PRF of the gasserian ganglion in terms of pain relief and complications in our clinic.

\section{Material and Methods}

The study was approved by the research ethics committee and all patients gave their written consent to participate in the study. Fourteen patients with idiopathic TN who had undergone combined RFT and PRF of the gasserian ganglion in our clinic were evaluated in our study. Brain magnetic resonance imaging had revealed no secondary causes of the TN. All of the patients ( 5 men and 9 women, aged between 54 and 79 years, mean age 64 years) had pain on the mandibular or the maxillary branch of the trigeminal nerve or both. They had a severe pain [Numeric Rating scale (NRS) pain score $\geq 8$ ] that was unresponsive to appropriate medical therapy. None of the patients had previously undergone interventional treatments including chemical ablation, balloon compression surgery, gamma knife or microvascular decompression. Seven patients had undergone RFT for the same complaint in our clinic once previously.

Electrocardiography, blood pressure, and arterial oxygen saturation were continuously monitored, and i.v. access put in place. Nasal oxygen was given to the patients during procedure. The patients were made to lie in a supine position with the head slightly extended. All procedures were performed under fluoroscopy which was adjusted to show the foramen ovale as the $\mathrm{C}$-arm was rotated $15^{\circ}$ obliquely to the ipsilateral affected side and $30^{\circ}$ caudally to produce a submental view. After disinfecting the puncture site, the skin was injected with a $2 \%$ solution of prilocaine $2 \mathrm{~cm}$ lateral from the angle of the mouth at the site of the TN. A 22-gauge, $10 \mathrm{~cm}$ RF needle with $5 \mathrm{~mm}$ active tip was directed towards foramen ovale using a tunnel view. Once the needle was in the foramen ovale, the C-arm was rotated laterally to ascertain the depth of penetration. The tip of the electrode was positioned appropriately in the gasserian ganglion. Electrical stimulation was administered at 50 $\mathrm{Hz}$ to determine the sensory threshold and at $2 \mathrm{~Hz}$ to determine the motor threshold. All patients reported paraesthesia at the area of the original pain and motor response was absent at voltages lower than $0.4 \mathrm{~V}$. After the position of the needle was confirmed, PRF $\left(42^{\circ} \mathrm{C}, 45 \mathrm{~V}, 20 \mathrm{~ms}, 120\right.$ seconds) was administered, and then RFT ( $65^{\circ} \mathrm{C}$, 90 seconds) was performed to the gasserian ganglion. If the patients had more than one branch involved, the same procedure was repeated for the other affected branch with the same parameters. The patients were sedated by injection of $1 \mathrm{mg} / \mathrm{kg}$ propofol during the RF procedures.

The patients were observed and monitored in the recovery room and discharged the following day. The post-operative pain relief and complications were evaluated at 1-, 6-, 12- and, 24- months after treatment. The patients were questioned through a telephone interview and pain was assessed using the numeric rating scale (NRS) $(0=$ no pain, $10=$ worst pain).

\section{Results}

A total of 14 patients who underwent RFT and PRF treatment of the gasserian ganglion for TN were evaluated in this study. The baseline characteristics of the patients are shown in Table 1. Twelve patients were interviewed by telephone for long-term follow-

Table 1. Demographic characteristics of the patients

\begin{tabular}{lcc}
\hline & Mean & Range \\
\hline Age & 69.5 & $60-79$ \\
Female/Male & $8 / 4$ & \\
Duration of preoperative pain (month) & 14 & $6-24$ \\
Preoperative NRS & 8.3 & \\
Right/left & $8 / 4$ & \\
V2/V3/both & $5 / 4 / 3$ & \\
\hline
\end{tabular}

NRS: Numeric Rating Scale. 
Table 2. Numeric rating scale scores and number of patients without pain before and 1-,6-,12-, and 24- months after procedure

\begin{tabular}{lccccc}
\hline & Pretreatment & 1 month & $\mathbf{6}$ months & 12 months & 24 months \\
\hline NRS & 8.33 & 2.16 & 2.83 & 4.33 & 5.75 \\
Number of patients without pain & & $10 / 12$ & $8 / 12$ & $5 / 12$ & $2 / 12$ \\
$(\mathrm{NRS}<3)(\mathrm{n})(\%)$ & & $(83.3 \%)$ & $(66.6 \%)$ & $(41.6)$ & $(16.6 \%)$ \\
\hline
\end{tabular}

NRS: Numeric rating scale.

up, while 2 patients were lost during the follow-up period. Ten patients (83.3\%) reported significant pain relief (NRS $<3$ ) at 1 month following the treatment, while 8 patients (66.6\%) at 6 months, 5 patients (41.6) at 12 months, and 2 patients (16.6\%) at 24 months were pain-free. Two of the patients did not have pain relief (VAS $\geq 3$ ), and 2 patients were still pain-free by the $24^{\text {th }}$ month (Table 2). The mean time of pain relief was 14 months.

One patient had numbness in the tongue for about a year, while in the other patients, no serious complications were reported.

\section{Discussion}

Trigeminal neuralgia has been treated by RFT of gasserian ganglion effectively. ${ }^{[7]}$ However, it has postoperative complications such as facial numbness, decreased corneal reflex, and masseter weakness. ${ }^{[2,3]}$ More recently, PRF has been introduced to modulate pain perception without damaging the nerve. ${ }^{[8,9]}$ Studies using PRF treatment for TN have reported disparate results. For example, while Erdine et al..$^{[4]}$ and Fang et al. ${ }^{[5]}$ reported that PRF was not effective for the treatment of pain in trigeminal neuralgia patients, some studies showed that increasing the duration of PRF (4-6 minutes) could lead to better results..$^{[10,11]}$ Also, Chua et al. ${ }^{[10]}$ showed that PRF application for 6 minutes at $45 \mathrm{~V}, 4 \mathrm{~Hz}, 10$ $\mathrm{ms}$ to the gasserian ganglion provided excellent pain relief ( $>80 \%$ pain relief) at 2,6 , and 12 months at $73.5 \%, 61.8 \%$ and, $55.9 \%$, respectively. Satisfactory pain relief (50-80\% pain relief) at 2,6 , and 12 months were $14.7 \%, 17.6 \%$ and, 17.6 , respectively. In our study, the time of pain relief 6,12 , and 24 months after the procedure was $66.6 \%, 41.6 \%$ and, $16.6 \%$. Our success rate might be low because inclusion of the patients who had received previous RFT and low degree $\left(65^{\circ} \mathrm{C}\right)$ of RFT.
Previous studies have reported initial pain relief rates from RFT of the trigeminal ganglion between $85 \%$ and $97 \% \cdot{ }^{[12-15]}$ In our study, the initial pain relief rate was $83.3 \%$. The earlier reports observed that the time of mean pain recurrence was 24 to 68 months. ${ }^{[12,13,15]}$ In our study, recurrence was seen after 3 months first-time and 2 patients were still pain-free in the $24^{\text {th }}$ month.

Yoon KB et al. ${ }^{[14]}$ demonstrated that the time of pain relief 1,2 and 11 years after the percutaneous RFT was $65 \%, 49 \%$ and $26 \%$, respectively in 108 RFT of 81 patients with TN and they reported dysaesthesia in 20 patients, corneal numbness in 12 patients and masseter weakness in 3 patients. Mark V. Koning et al. ${ }^{[16]}$ demonstrated that a lower sensory stimulation threshold during treatment was associated with better patient satisfaction, improved pain relief, and trended toward more hypesthesia. In their study, major side effects were hypesthesia (56\%), dry eye (20\%), and masseter muscle weakness (12\%). Hence, Zhao et al. ${ }^{[2]}$ suggested that RFT combined with PRF could help eliminate post-operative complications of TN such as facial numbness, masseter muscle weakness, and decreased corneal reflex. In our study, postoperative complications were seen only in one patient.

The exact mechanism of PRF is unknown and it is still being investigated. ${ }^{[17]}$ Several studies have investigated the factors that have an impact on PRF. Luo et al. ${ }^{[18]}$ showed that increasing intraoperative RF output voltage and electrical field intensity improves the outcome of PRF treatment. Although the mechanism of PRF remains completely unknown, studies like these may help to clarify its effects.

\section{Conclusion}

A combination of RFT with PRF could help eliminate postoperative complications of trigeminal neuralgia. 
We sugesst that combining RFT and PRF therapy may serve to decrease the side effects but not increase the pain relief. The same interventions with different parameters and different time of radiofrequency of the gasserian ganglion may generate better results. Future studies will investigate this possibility.

\section{Conflict-of-interest issues regarding the authorship or article: None declared.}

\section{Peer-reiew: Externally peer-reviewed.}

\section{References}

1. Kosugi S, Shiotani M, Otsuka Y, Suzuki T, Katori N, Hashiguchi $\mathrm{S}$, et al. Long-term outcomes of percutaneous radiofrequency thermocoagulation of gasserian ganglion for 2nd- and multiple-division trigeminal neuralgia. Pain Pract 2015;15(3):223-8. [CrossRef]

2. Zhao WX, Wang Q, He MW, Yang LQ, Wu BS, Ni JX. Radiofrequency thermocoagulation combined with pulsed radiofrequency helps relieve postoperative complications of trigeminal neuralgia. Genet Mol Res 2015;14(3):7616-23.

3. Thapa D, Ahuja V, Dass C, Verma P. Management of refractory trigeminal neuralgia using extended duration pulsed radiofrequency application. Pain Physician 2015;18(3):E433-5.

4. Erdine S, Ozyalcin NS, Cimen A, Celik M, Talu GK, Disci R. Comparison of pulsed radiofrequency with conventional radiofrequency in the treatment of idiopathic trigeminal neuralgia. Eur J Pain 2007;11(3):309-13. [CrossRef]

5. Fang L, Ying S, Tao W, Lan M, Xiaotong Y, Nan J. 3D CTguided pulsed radiofrequency treatment for trigeminal neuralgia. Pain Pract 2014;14(1):16-21. [CrossRef]

6. Kang KN, Park IK, Suh JH, Leem JG, Shin JW. Ultrasoundguided Pulsed Radiofrequency Lesioning of the Phrenic Nerve in a Patient with Intractable Hiccup. Korean J Pain 2010;23(3):198-201. [CrossRef]

7. Motamedi MH, Rahmat $H$, Bahrami E, Sadidi A, Navi F, Asadollahi $M$, et al. Trigeminal neuralgia and radiofrequency. J Calif Dent Assoc 2009;37(2):109-14.

8. Van Zundert J, Patijn J, Kessels A, Lamé I, van Suijlekom H, van Kleef M. Pulsed radiofrequency adjacent to the cervical dorsal root ganglion in chronic cervical radicular pain: a double blind sham controlled randomized clinical trial. Pain 2007;127(1-2):173-82. [CrossRef]

9. Rehman SU, Khan MZ, Hussain R, Jamshed A. Pulsed radiofrequency modulation for lingual neuralgia. $\mathrm{Br} J$ Oral Maxillofac Surg 2012;50(1):e4-5. [CrossRef]

10. Chua NH, Halim W, Beems T, Vissers KC. Pulsed radiofrequency treatment for trigeminal neuralgia. Anesth Pain Med 2012;1(4):257-61. [CrossRef]

11. Van Zundert J, Brabant S, Van de Kelft E, Vercruyssen A, Van Buyten JP. Pulsed radiofrequency treatment of the Gasserian ganglion in patients with idiopathic trigeminal neuralgia. Pain 2003;104(3):449-52. [CrossRef]

12. Tatli $M$, Satici $O$, Kanpolat $Y$, Sindou M. Various surgical modalities for trigeminal neuralgia: literature study of respective long-term outcomes. Acta Neurochir (Wien) 2008;150(3):243-55. [CrossRef]

13. Kanpolat Y, Savas A, Bekar A, Berk C. Percutaneous controlled radiofrequency trigeminal rhizotomy for the treatment of idiopathic trigeminal neuralgia: 25 -year experience with 1,600 patients. Neurosurgery 2001;48(3):524-32. [CrossRef]

14. Yoon KB, Wiles JR, Miles JB, Nurmikko TJ. Long-term outcome of percutaneous thermocoagulation for trigeminal neuralgia. Anaesthesia 1999;54(8):803-8. [CrossRef]

15. Udupi BP, Chouhan RS, Dash HH, Bithal PK, Prabhakar H. Comparative evaluation of percutaneous retrogasserian glycerol rhizolysis and radiofrequency thermocoagulation techniques in the management of trigeminal neuralgia. Neurosurgery 2012;70(2):407-12. [CrossRef]

16. Koning MV, Koning NJ, Koning HM, van Kleef M. Relationship between Sensory Stimulation and Side Effects in Percutaneous Radiofrequency Treatment of the Trigeminal Ganglion. Pain Pract 2014;14(7):581-7. [CrossRef]

17. Cohen SP, Peterlin BL, Fulton L, Neely ET, Kurihara C, Gupta A, et al. Randomized, double-blind, comparative-effectiveness study comparing pulsed radiofrequency to steroid injections for occipital neuralgia or migraine with occipital nerve tenderness. Pain 2015;156(12):2585-94. [CrossRef]

18. Luo F, Meng L, Wang T, Yu X, Shen Y, Ji N. Pulsed radiofrequency treatment for idiopathic trigeminal neuralgia: a retrospective analysis of the causes for ineffective pain relief. Eur J Pain 2013;17(8):1189-92. [CrossRef] 